\title{
Lähiruoan lisäarvot ja markkinointi paikallisessa elintarvikeketjussa
}

\author{
Jaana Paananen ${ }^{1)}$ ja Sari Forsman ${ }^{2)}$ \\ ${ }^{1)}$ MTT Taloustutkimus, Luutnantintie 13,00410 Helsinki, jaana.paananen@mtt.fi \\ ${ }^{2)}$ MTT Taloustutkimus, Luutnantintie 13,00410 Helsinki, sari.forsman@mtt.fi
}

\section{Johdanto}

Elintarvikemarkkinoiden globalisoitumisen myötä kuluttajien ja ruoka-alan ammattilaisten kiinnostus ruoan alkuperästä ja elintarvikeketjun läpinäkyvyydestä on lisääntynyt. Tämä on lisännyt kiinnostusta vaihtoehtoisiin ruokajärjestelmiin kuten paikallisiin elintarvikeketjuihin. Tässä tutkimuksessa tarkasteltiin lähiruokatoiminnan mahdollisuuksia suurkeittiössä, vähittäiskaupassa ja maaseutumatkailussa. Lähiruokatoiminnalla tarkoitetaan yleisesti mahdollisimman lähellä ruoan kulutusta tapahtuvaa elintarvikeraaka-aineiden niin tuotantoa, jalostusta kuin myyntiäkin.

Paikallisuus on elintarviketuotannon kehittämisessä suhteellisen uusi aihealue. Paikallisessa ruokatuotannossa yhdistyvät sekä ympäristötekijät että tuotannon sosiaaliset ja eettiset vaikutukset (Seppälä ym. 2002, s. 33). Paikallisuus sinänsä ei ole uusi ulottuvuus ruoantuotannossa ja -kulutuksessa, mutta sen merkitys on nostettu uudella tavalla esiin globalisaatio-lokaalisaatio -vastakkainasettelussa. Lähiruokatoiminnalla on keskeinen rooli myös maaseudun elintarvikeyrittäjyyden kehittämisessä. Lähiruokajärjestelmät edustavat uusia toimintamalleja elintarvikeketjussa ja maaseudun kehittämisessä (Marsden \& Arce 1995, Marsden 2000, Marsden ym. 2000, La Trobe \& Acott 2000).

Tutkimuksessa lähiruokaa tarkasteltiin tuotteistamis- ja markkinointimahdollisuutena maaseudun pienten elintarvikeyritysten näkökulmasta. Tavoitteena oli tarkastella lähiruokatuotantoa ja -toimintaa osana elintarvikeketjun asiakaslähtöistä lisäarvon muodostamista. Lähtökohtana oli oletus, että lähiruokatoiminta muodostaa ketjun eri toimijoiden näkökulmasta hyötyjä, jotka luovat lisäarvoa pienyrityksen ja asiakkaan välisessä kaupallisessa suhteessa. Tämä perustui siihen, että elintarvikkeiden suoralla tarjontaketjulla on myönteinen vaikutus sekä tuotteiden ominaisuuksiin että myyjäostajasuhteeseen. Tuotteen tuoreuden oletetaan olevan parempi suorassa toimituksessa tuottajalta asiakkaalle kuin epäsuorassa, usean välivarastoinnin kautta kulkevassa toimituksessa (Markula 1999, s. 14). Lisäksi suora tarjontaketju mahdollistaa aukottoman tiedonvaihdon myyjä-ostajasuhteen eri vaiheissa (Aro 1998, s. 30). Suoran tarjontaketjun myönteisten vaikutuksien kautta sen oletetaan lisäävän eri toimijoiden menestymistä elintarvikeketjussa. Tutkimuksen tavoitteena oli selvittää paikallisten tarjontaketjujen mahdollisuuksia ja toimintaedellytyksiä elintarvikealan maaseutuyritysten kilpailukyvyn ja menestymisen mahdollisuuksien edistämiseksi.

Tutkimuksen teoreettinen asemointi perustui vaihtoehtoiseen tapaan tarkastella elintarvikkeiden tarjontaketjua sekä asiakkaan arvon muodostumisen mallintamiseen. Tarjontaketjujen tarkastelu perustui tarjontaketjujen johtamisen ja hallinnan teorioihin. Lähiruokatoiminnan näkökulmasta toimijoiden muodostamat verkostot nähdään potentiaalisempana arvon muodostajina asiakkaille kuin perinteiset perättäisesti, vertikaalisesti ja usein moniportaisesti toimivat tarjontaketjut. Verkostoajattelu perustuu eri toimijoiden läheisyyteen ja vastavuoroiseen riippuvuuteen tiedosta ja sen vaihdosta sekä läpinäkyvään toimintatapaan elintarvikeketjussa. Vastaavasti asiakasarvon muodostumista paikallisessa elintarvikeketjussa tarkasteltiin eri toimijoiden lähiruokaan ja lähiruokatoimintaan liittämien hyöty-, uhraus- ja riskitekijöiden sekä asiakasarvohierarkia-mallin pohjalta. Toimijoiden keskinäiseen läheisyyteen ja tiiviiseen vuorovaikutukseen perustuva lähiruokatoiminta tarjoaa sekä arvotekijöiden että arvoa tuottamattomien tekijöiden tunnistamiselle ja määrittämiselle hyvät lähtökohdat.

Yrityksissä lisäarvoa luovia tekijöitä muodostuu fyysisistä tuoteominaisuuksista, palvelu- tai mielikuvatekijöistä sekä yrityksen tuotanto- ja toimintatapaan liittyvistä tekijöistä. Näillä tekijöillä muodostetaan lisäarvoa erityisesti silloin, kun tekijät tai toimintatavat ovat yhdenmukaisia asiakkaiden toimintatapojen ja arvojen kanssa. Vastaavasti asiakkaalle lisäarvo muodostuu tuotteesta saadusta hyödystä sekä tuotteen saamiseksi käytetystä ajallisista ja rahallisista uhrauksista sekä riskeistä (Kemperman ja van Engelen 1999, Ravald ja Gröönroos 1996, Ravald 2001). Lähiruokatoiminnassa yrityksen tuote- ja palveluominaisuuksilla tulee olla hyötyä tuottavia sekä myös uhrauksia ja riskejä alentavia seurausvaikutuksia asiakkaille, jotta toimintamalli koettaisiin paremmaksi kuin perinteiset tarjontaketjut (Woodruff 1997). Asiakkaiden odotusten ja kokemusten välinen tasapaino mm. yrityksen tuotteiden laatua kohtaan vahvistaa asiakastyytyväisyyden ja -uskollisuuden kautta yrityksen taloudellista suorituskykyä (Stoelhorst 1997, ref. Kemperman ja van Engelen 1999). 


\section{Aineisto ja menetelmät}

Tutkimuksen empiirinen osuus koostui kolmesta case-osiosta; elintarvikealan maaseutuyritysten lähiruoan markkinointimahdollisuuksia selvitettiin 1) vähittäiskaupassa, 2) suurkeittiössä ja 3) maaseutumatkailussa. Tutkimus toteutettiin kvalitatiivisella tutkimusotteella, sillä lähiruokatoimintaa voidaan pitää sen verran uutena ilmiönä, että sen tutkiminen olisi voinut olla hankalaa pelkästään kvantitatiivisin menetelmin. Kvalitatiivinen lähestymistapa antoi mahdollisuuden tarkastella lähiruokatoimintaa ilmiönä syvällisesti ja kokonaisvaltaisesti. Tutkimusasetelmana oli tapaustutkimus, koska lähiruokatoimintaa ei vielä voida pitää vakiintuneena ilmiönä. Tapaustutkimuksen aineiston keräämisessä on tärkeää, että erilaiset näkökulmat tulevat esille (Yin 1994). Valittu lähestymistapa antoi siten mahdollisuuden lähestyä tutkimusilmiötä intensiivisesti ja eri näkökulmista sekä ilmiön ainutlaatuisten että yleisten piirteiden tunnistamiseksi (ks. Yin 1994, Stake 1995).

Aineisto hankittiin puolistrukturoiduilla teemahaastatteluilla. Tutkimuksessa haastateltiin kaikkiaan 62 henkilöä, jotka edustivat elintarvikealan maaseutuyrityksiä, vähittäiskauppaa, markkinointija logistiikkapalveluyrityksiä, kaupallisia ja julkisia suurkeittiöitä sekä maaseutumatkailua. Haastattelut tehtiin ajalla marraskuu 2000 - joulukuu 2002 Pohjois-Karjalan, Pohjois- ja Etelä-Savon, KeskiSuomen sekä Pirkanmaan maakuntien alueilla. Teemahaastattelurungon rakentamisen perustana käytettiin aiempia tutkimuksia ja teoreettisia näkemyksiä sekä tutkijoiden hankkimaa tietoa lähiruokatuotannon ja -toiminnan nykytilasta.

Lähiruokatoimintaan liittyvien lähtökohtaoletusten perusteella muodostettiin tutkimukselle teoreettiset näkökulmat vaihtoehtoisesta tarjontaketjusta ja lisäarvon muodostumisesta, ja ne koottiin malliksi teoreettisessa viitekehyksessä (Paananen ja Forsman 2001, s. 34). Aineiston analyysi tehtiin pitkälti induktiivisesti käyttäen kuitenkin teoreettista mallia viitteellisenä tarkastelukehikkona. Luotettavuuden varmistamiseksi analyysiprosessissa noudatettiin periaatetta, jonka mukaan tiedonlähteiden ja tulosten päättelyketjua tulee voida tarkastella molempiin suuntiin, havainnoista johtopäätöksiin ja johtopäätöksistä takaisin yksittäiseen havaintoon (Yin 1994, s. 98, ks. tutkimuksen luotettavuudesta tarkemmin Paananen ja Forsman 2001, 2003).

Tutkimuksen analyysimenetelmänä sovellettiin näytteiden sopivuuden eli pattern-matching -analyysimallia, jossa verrattiin teoreettisia oletuksia ja näytteiden perusteella saatujen tulosten yhteensopivuutta (ks. Yin 1994). Aineistosta nousi esille myös runsaasti ilmiön olemusta kuvaavaa uutta perustietoa, mikä täydensi lisäarvon muodostumisen tarkastelua. Tutkimustulokset ovat yleistettävissä ensisijaisesti tutkimusaineistoon; tutkimusilmiötä ajatellen niitä tulee tarkastella suuntaa antavina.

\section{Tulokset ja tulosten tarkastelu}

Tutkimus osoitti, että lähiruoka käsitteenä ei ole yksiselitteinen. Elintarvikeketjun eri toimijat määrittelivät lähiruokakäsitteen hieman eri tavoin, mutta määritelmissä oli tunnistettavissa yhteisiä piirteitä (taulukko 1). Keskeisintä eri toimijoiden lähiruokamäärittelyissä oli ruoan tuotannon ja kulutuksen maakunnallisuus ja ruokaketjussa toimivien keskinäinen läheisyys.

Eri toimijat suhtautuivat lähiruokaan myönteisesti ja liittivät siihen useita positiivisia tuoteominaisuuksia ja toiminnallisia ulottuvuuksia. Lähiruoan keskeisimpinä ominaisuuksina pidettiin tuoreutta, paikallisia makuja ja erilaisuutta teollisesti valmistetuista tuotteista. Lyhyt ja suora tarjontaketju mahdollistaa tuotteiden joustavat toimitukset, toimijoiden vuorovaikutteisen kumppanuussuhteen sekä informaation tehokkaan hyödyntämisen elintarvikeketjussa. Lähiruoassa nähdäänkin tärkeämpänä sen avulla saavutettavat positiiviset vaikutukset ja asiakaslähtöinen toiminta kuin sen määrittämiseksi asetettavat tarkat maantieteelliset rajat. Tutkimuksen tulokset tukevat lähtökohdaksi asetettua oletusta lähiruokatoiminnan lisäarvoa tuottavista tekijöistä.

Lähiruokatoiminta nähtiin vahvasti pienten elintarvikeyritysten strategiana, joiden toimintatavassa keskeistä on käsityömäisyys ja yrittäjän vastuu koko valmistus- ja markkinointiprosessista lopullisille asiakkaille asti. Tämä edesauttaa pienyrityksiä tuotteiden ja palveluiden erilaistamisessa ja lisäarvottamisessa sekä edelleen erottautumisessa massatuotannosta. 
Taulukko 1. Yhteenveto ulottuvuuksista, joita eri toimijat liittävät lähiruokaan ja lähiruokatuotantoon.

\begin{tabular}{|c|c|c|c|}
\hline $\begin{array}{l}\text { Elintarvikealan } \\
\text { pienyritykset }\end{array}$ & Vähittäiskauppa & Suurkeittiö & Maaseutumatkailu \\
\hline Maakunnallisuus & $\begin{array}{l}\text { Valmistettu pienissä yri- } \\
\text { tyksissä }\end{array}$ & Vuodenaikatuotteet & Ruokaketjun läpinäkyvyys \\
\hline Saatavuus paikallista & Kotiruokatyyppistä & Puhtaus ja tuoreus & $\begin{array}{l}\text { Luonnosta saatavien tuot- } \\
\text { teiden hyödynnettävyys }\end{array}$ \\
\hline $\begin{array}{l}\text { Ei valtakunnallisessa jake- } \\
\text { lussa }\end{array}$ & Paikalliset raaka-aineet & $\begin{array}{l}\text { Suorat ja pienet toimitus- } \\
\text { määrät }\end{array}$ & Puhtaus \\
\hline $\begin{array}{l}\text { Raaka-aineiden jäljitettä- } \\
\text { vyys }\end{array}$ & Pienimuotoisuus & Ruokakulttuurien ylläpito & Tuoreus \\
\hline $\begin{array}{l}\text { Koko ketju raaka-aineen } \\
\text { tuotannosta jalostukseen ja } \\
\text { kulutukseen }\end{array}$ & Käsityömäisyys & $\begin{array}{l}\text { Erottuu teollisesta tuottees- } \\
\text { ta }\end{array}$ & Hyvä maku \\
\hline Tuoreus & $\begin{array}{l}\text { Erilaistettu massatuotan- } \\
\text { nosta }\end{array}$ & Alkuperän säilyminen & Maakunnallisuus \\
\hline $\begin{array}{l}\text { Pienimuotoinen ja käsi- } \\
\text { työmäinen yrittäjyys }\end{array}$ & $\begin{array}{l}\text { Paikalliset makutottumuk- } \\
\text { set }\end{array}$ & $\begin{array}{l}\text { Ruoan kasvatuksellinen } \\
\text { arvo }\end{array}$ & \\
\hline Henkilöitynyt tuote & $\begin{array}{l}\text { Lyhyt kuljetusmatka raaka- } \\
\text { aineiden tuotannosta asiak- } \\
\text { kaan pöytään }\end{array}$ & Ruoan turvallisuus & \\
\hline Alueellinen kehittäminen & & Alueen työllistyminen & \\
\hline $\begin{array}{l}\text { Ruokaperinteiden säilymi- } \\
\text { nen }\end{array}$ & & $\begin{array}{l}\text { Ammattitaitoinen ruoan- } \\
\text { valmistus }\end{array}$ & \\
\hline
\end{tabular}

Lähiruoan hyödyntäminen kaupan markkinointivahvuutena oli vähäistä. Vähittäiskaupassa lähituotteet nähdään enemmänkin täydentävinä erikoistuotteina, ja niiden imagollinen merkitys on myyntiä suurempi. Paikallisten ruokatuotteiden avulla voidaan luoda kuluttajille myönteistä kokonaismielikuvaa myymälästä ostopaikkana. Kokemukset paikallisista ruokatuotteista ovat olleet pääsääntöisesti myönteisiä. Etenkin silloin kun lähituotteiden valmistajat ovat asiakkaille tuttuja, ne herättävät luottamusta. Suuremmilla myymälöillä näyttää olevan paremmat mahdollisuudet ottaa paikallisia ruokatuotteita valikoimiin; pienemmissä myymälöissä tilanpuute rajoittaa valikoimien laajentamista. Lähituotteet ovat usein hinnaltaan korkeampia kuin tuotevalikoiman perustuotteet. Paikallisuudella sinänsä ei kaupan näkökulmasta ole perustetta korkeammalle hinnalle, vaan tuotteella tulee olla myös muita lisäarvoja sekä kaupalle että kuluttajille.

Suurkeittiöitä, erityisesti kunnallisia ateriapalveluyksiköitä voidaan pitää lähiruoan potentiaalisimpana markkinointikanavana pienyrityksille. Suurkeittiöissä on kiinnostusta sekä lähi- että luomutuotteisiin. Kysyntää olisi huomattavasti nykyistä tarjontaa enemmän. Tällä hetkellä lähitoimittajat nähdään lähinnä täydennystoimittajina, sillä lähituotteiden vähäinen saatavuus ei vielä mahdollista niiden hyödyntämistä suuremmassa mittakaavassa. Suurkeittiöissä lähiruokaan liitettiin vuodenaikatuotteiden hyödyntäminen, kasvatuksellinen merkitys sekä parempi viihtyminen suurkeittiötyössä. Lähituotteiden hyödyntämisellä on mahdollisuus pienentää kokonaishävikkiä. Lähitoimittajien etuna nähtiin joustavuus, lyhyen varoitusajan toimitusvarmuus ja suorat kontaktit ostajiin.

Maaseutumatkailun markkinapotentiaalia lähiruoassa ei tällä hetkellä hyödynnetä riittävästi, vaikka lähituotteiden käyttö maaseutumatkailussa onkin suhteellisen yleistä. Maaseutumatkailu on kuitenkin eräs kasvavista maaseutuelinkeinon aloista, ja se tarjoaa siten lukemattomia tuotteistamismahdollisuuksia lähiruokaa tuottaville pienyrittäjille. Ruoka on olennainen osa kokonaismatkailupakettia, jolloin se luonnollisesti vaikuttaa siihen kokonaismielikuvaan, joka asiakkaalle matkailukokemuksesta ja maaseudun hyvinvoinnista syntyy. Paikallisia ruokatuotteita voitaisiin tuoda maaseutumatkailussa tietoisemmin esille. Tuotteistamisessa voidaan hyödyntää elämysajattelua. Esimerkiksi tarinan ja tiedon liittäminen ruokaan tuo sosiaalista ja kulttuurista lisäarvoa. Tarina tai tieto voi perustua esimerkiksi perinteisiin tai paikalliseen kulttuuriin.

\section{Johtopäätökset}

Elintarvikemarkkinoillamme on vielä paljon hyödyntämättömiä mahdollisuuksia lähiruoan käytön lisäämisessä, tuotteistamisessa ja markkinoinnissa. Vähittäiskaupoissa lähiruoka koettiin paikallisia makuja ylläpitävänä ja valikoimia erilaistavana tekijänä. Kuitenkin vain muutamat vähittäiskaupat 
nostivat lähiruokaa näkyvästi esille myymälän valikoimissa ja yleisilmeessä. Myös maaseutumatkailussa hyödynnettiin jossain määrin oman tilan tai lähialueen tuotteita, mutta niiden hyödyntäminen tietoisena markkinointimahdollisuutena oli vielä vähäistä. Vastaavasti suurkeittiöissä lähiruokaa haluttiin hyödyntää sen positiivisten käyttöominaisuuksien lisäksi myös kasvatuksellisessa merkityksessä.

Paikallisten ruokatuotteiden hyödyntämistä voidaan edistää monin tavoin. Keskeisimpiä kehittämisalueita ovat lähituotteiden aktiivinen tarjonta, asiakasarvopohjaiset markkinointiargumentit, lähiruoan tunnistettavuuden parantaminen, lähiruoan imagoa tukevat logistiset ratkaisut ja eri toimijoiden strategiseen kumppanuuteen perustuva yhteistyö. Lähiruokatoiminnan kehittäminen vaatii myös yhteiskunnan tukea. Tämän tutkimuksen perusteella voidaan nostaa esiin seuraavat kehittämisasiat:

- Kunta/maakuntatasolla tulee pohtia lähiruokatoiminnan strategista merkitystä alueen elinvoimaisuudelle, erityisesti kunnallisten ruokapalvelujen merkitystä alueen hyvinvointiin ja menestymiseen

- Kunta/maakuntatasolla tulee selvittää julkisten hankintojen mahdollisuudet hyödyntää lähialueiden maatalous- ja elintarviketuotantoa uudella ja kilpailukykyisellä tavalla

- Elintarvikealan pienyrityskulttuuri edellyttää vahvistamista

- Viranomaissäädöksissä tulee kiinnittää huomiota valvonnan hintaan pienyritysten osalta

- Ammattitaitoisen työvoiman sekä työntekijöille kuuluvien lakisääteisten palveluiden saatavuus tulee turvata maaseutualueilla

- Kuluttajien aktivoiminen ja tiedon lisääminen ruoan turvallisuudesta ja terveellisyydestä, ruokakulttuureista ja -perinteistä, kuluttajien vaikutusmahdollisuuksista, yhteiskunnallisista arvoista ja politiikasta

\section{Kirjallisuus}

Aro, J. 1998. Suurkeittiöt elintarvikealan pienyritysten markkinointikanavana. Maatalouden taloudellisen tutkimuslaitoksen selvityksiä 3/98. Helsinki. 44 s. ISBN 951-687-015-5.

Kemperman, J. E. B. \& van Engelen, M. L. 1999. Operationalizing the customer value concept. Teoksessa: Hildebradt, L., Annacker, D. \& Klapper, D.(toim.). Marketing and Competition in the information age. Proceedings of the $28^{\text {th }}$ EMAC Conference. Berlin: Humboldt University. 235 s. ISBN 3-00-004187-7.

La Trobe, H. L. \& Acott, T. G. 2000. Localising the global food system. International Journal of Sustainable Development and World Ecology 7:309-320.

Markula, J. 1999. Suurkeittiöiden elintarvikeostot maaseutuyrityksiltä. Maatalouden taloudellisen tutkimuslaitoksen selvityksiä 1/99. Helsinki. 44 s. ISBN 951-687-038-4.

Marsden, T. 2000. Food Matters and the Matter of Food: Towards a New Food Governance. Sociologia Ruralis 40(1): 20-29.

Marsden, T. K. \& Arce, A. 1995. Constructing quality: emerging food networks in the rural transition. Environment and Planning A 27:1261-1279.

Marsden, T., Banks, J. \& Bristow, G. 2000. Food Supply Chain Approaches: Exploring their Role in Rural Development. Sociologia Ruralis 40(4): 425-438.

Paananen, J. \& Forsman, S. 2001. Lähiruoka elintarvikealan maaseutuyritysten ja suurkeittiöiden kokemana. Taloustutkimus (MTTL), tutkimuksia 252. Helsinki. 94 s. ISBN 951-687-118-6.

Paananen, J. \& Forsman, S. 2003. Lähiruoan markkinointi vähittäiskauppoihin, suurkeittiöihin ja maaseutumatkailuyrityksiin. Maa- ja elintarviketalous 24. Vammalan Kirjapaino Oy. 62 s., 8 liitettä. ISBN 951-729-761-0

Ravald, A. 2001. A View of Value - The Customer Value Process Approach. A paper presented in the $30^{\text {th }}$ EMAC Conference "Rethinking European Marketing". Norway, May 8 - 11, 2001.

Ravald, A. \& Gröönroos, C. 1996. The Value Concept and Relationship Marketing. European Journal of Marketing 30(2):19-30.

Seppälä, A., Voutilainen, P., Mikkola, M., Mäki-Tanila, A., Risku-Norja, H., Soini, K., Vehmasto, E. \& Yli-Viikari, A. 2002. Ympäristö ja eettisyys elintarviketuotannossa - todentamisen ja tuotteistamisen haasteet. MTT:n selvityksiä 11. Jokioinen: MTT. 72 s. ISBN 951-729-690-8.

Stake, R. E. 1995. The art of case study research. Thousand Oaks, California: Sage Publications. 175 s. ISBN 08039-5767-X.

Stoelhorst, J-W. 1997. In Search of a Dynamic Theory of the Firm. Doctoral dissertation. University of Twente. Woodruff, R. B. 1997. Customer value: The next source for competitive advantage. Journal of the Academy of Marketing Science 25(2): 139-153.

Yin, R. K. 1994. Case Study Research - Design and Methods. $2^{\text {nd }}$ edition. Sage Publications, USA. 212 s. ISBN 0-8039-5663-0. 